\title{
Survival of Listeria monocytogenes in turmeric-salt marinated short mackerel (Rastrelliger brachysoma) under isothermal storage temperature
}

\author{
Ummul-Izzatul, Y., "Nor-Khaizura, M.A.R., Ghazali, F.M., Son, R., Shafiqa-Atikah, M.K. \\ and Nur-Syifa', J.
}

Department of Food Science and Technology, Faculty of Food Science and Technology, Universiti Putra Malaysia, 43400 UPM Serdang, Selangor Darul Ehsan, Malaysia

\author{
Article history: \\ Received: 24 October 2019 \\ Received in revised form: 13 \\ March 2020 \\ Accepted: 4 April 2020 \\ Available Online: 15 April \\ 2020
}

\section{Keywords:}

Short mackerel (Rastrelliger brachysoma),

L. monocytogenes,

Turmeric-salt margination,

Isothermal storage

temperature

DOI:

https://doi.org/10.26656/fr.2017.4(S2).S06

\begin{abstract}
Short mackerel (Rastrelliger brachysoma) is a common fish consumed in Malaysia. The high protein content of fish makes it prone to contamination with bacteria, including Listeria monocytogenes. Therefore, the objective of this study is to control the growth of L. monocytogenes by marinating short mackerel with turmeric-salt and storing at various temperatures. The short mackerel was treated with $70 \%$ of ethanol before marinating with turmeric-salt in a ratio (1:1). The short mackerel were inoculated with a concentration of $10^{8} \mathrm{CFU} / \mathrm{mL}$ of L. monocytogenes and was stored at $0,5,10,15,20$, and $25^{\circ} \mathrm{C}$ for 21 days. The total microbial count and $L$. monocytogenes count were determined for every three days from 0 days to 21 days. The growth of $L$. monocytogenes in marinated mackerel was from $4.30 \log \mathrm{CFU} / \mathrm{g}\left(0\right.$ days at $\left.0{ }^{\circ} \mathrm{C}\right)$ to $5.22 \log \mathrm{CFU} / \mathrm{g}\left(0\right.$ days at $\left.25^{\circ} \mathrm{C}\right)$. While the total of L. monocytogenes counts in non-marinated (control), short mackerel increased significantly based on temperature and time from $4.98 \log \mathrm{CFU} / \mathrm{g}$ ( 0 days at 0 $\left.{ }^{\circ} \mathrm{C}\right)$ to $6.22 \log \mathrm{CFU} / \mathrm{g}\left(0\right.$ days at $\left.25{ }^{\circ} \mathrm{C}\right)$. These results indicated that the growth of $L$. monocytogenes in the presence of turmeric-salt slowed compared with the non-marinated product, although the growth of $L$. monocytogenes was gradually increased throughout 21 days of storage. There was a significant difference $(\mathrm{p}<0.05)$ in the growth of $L$. monocytogenes with the storage temperature. In conclusion, the turmeric-salt marination has the potential to slow the growth of L. monocytogenes in short mackerel by approximately $0.07 \log \mathrm{CFU} / \mathrm{g}-2.81 \log \mathrm{CFU} / \mathrm{g}$ of $\log$ reduction.
\end{abstract}

\section{Introduction}

The exposure of foodborne pathogens to environmental and preservation stresses can improve the safety of food products. Listeria monocytogenes is a common foodborne pathogen (Chen et al., 2017). Listeria is a small microorganism $(0.5 \mu \mathrm{m}$ diameter and only about 1 to $2 \mu \mathrm{m}$ in length). It is a regular Grampositive rod with rounded ends. Usually, Listeria cell is found as single cells or short chains and does not produce spores and capsules. The genus Listeria is composed of six species which are Listeria grayii, Listeria innocua, Listeria ivanovii, Listeria seeligeri and Listeria welshimeri. These five species are generally non -pathogenic (Fallah et al., 2013). They are aerobic to facultative anaerobic psychrotrophic bacteria with low $\mathrm{C}+\mathrm{G}$ content and high mortality rate (Jamali et al., 2015). L. monocytogenes is widely distributed through the environment with a high frequency of isolation in foods but relatively low incidence of listeriosis in the general population (Buchanan et al., 2017). Since L. monocytogenes responsible for human foodborne and animal pathogen, many studies focusing on farm environments and food processing (Ryser, 1957). Listeriosis is a potentially fatal disease that exhibits the symptoms of abortion, neonatal death, septicemia and meningitis (Chen et al., 2017). It can easily affect a pregnant woman, immunocompromised individuals, and newborn babies. There are many listeriosis outbreaks reported. In the previous study, 35 persons infected with this foodborne in the United States from December 2014 to January 2015 (Gurresch et al., 2016). It can be transmitted to humans by direct contact with infected animals during calving or lambing and the consumption of contaminated food. WHO concluded that foodborne listeriosis predominantly transmitted by nonzoonotic means. L. monocytogenes is an environmental organism whose primary route to humans is via food contaminated during production. It also being isolated from many 
environments including, water, soil, sewage, vegetation, animal feeds, farm environments, soil and food processing environments (Ryser, 1957). Based on a study conducted by (Wieczorek and Osek, 2017) among 301 samples of fresh and smoked fish tested, about 57 (18.9\%) were positive for L. monocytogenes. There have been many major outbreaks happened in the US and Europe involving the consumption of food that was contaminated with L. monocytogenes. Steps need to be implemented to prevent and control listeriosis outbreaks (Chen et al., 2017).

Fish is one of the most perishable food products. According to Pal et al. (2016), a number about 22,000 species of fish started to evolve from 480 million years ago (Pal et al., 2016). Numbers, colours, shapes, and sizes of fishes differ depending on their habitats. Gram and Dalgaard, (2002), reported that there is only a little amount of carbohydrate in fish, in contrary, it contains a high amount of free amino acids. The spoilage that happened from the fresh fish usually from the monitoring and controlling of storage temperature (Giannakourou et al., 2005). Fishes are classified in the cold-blooded aquatic vertebrates of the super-class Pisces because of the typically showing gills, fins, and streamLine body (Pal et al., 2016), (Han et al., 2017). Previous research work reported that Malaysian consumed as much as one and medium fish per day, thus denoted it as our essential food. Generally, fishes are known as nutritious, safe and give benefit to human, but as usual, the aquaculture products are also associated with certain food safety issues (Pal et al., 2016).

To date, there is various type of fishes available in the market. Rastrelliger brachysoma is a scientific name for short mackerel. It is from a family of Scrombidae and genus Rastrelliger. There are three species in this genus which are short mackerel (Rastrelliger brachysoma), Indian mackerel (Rastrelliger kanagurta) and Island mackerel (Rastrelliger faughni) (Basheer et al., 2015). These three species represent the essential fisheries resources in Southern Asian and Indo Pacific countries. It is known as an essential commercial small pelagic fish species migratory fish (oceanodromous). Consumers have a high preference for this species due to its availability and affordable price. Short mackerel available in Southeast Asia countries, including Malaysia, Cambodia, Indonesia, Thailand, and the Philippines (Tan et al., 2017).

Marination is a process that is used mainly for flavouring and at the same time, it also could slow down bacterial and enzymatic activity. It also provides structural changes, tenderness and textural changes with a prolonged shelf life (Siavash Maktabi et al., 2016).
Commonly, marination is used in the poultry industry, which increases raw yield at the processing plant (Nieminen et al., 2012). Marination can be applied by injecting, soaking, and tumbling with an aqueous solution that contains distinct ingredients (VlahovaVangelova and Dragoev, 2014). Some previous studies have been done focusing on seafood marinating by using holy basil, paper garlic (Maktabi et al., 2015), rosemary extract, yoghurt, tomato sauce, and spices. Nowadays, many other constituents being added in the food human eat such as synthetic preservatives, colourants, and antioxidants in order to extend the shelf life of the food (Siavash Maktabi et al., 2016). Marination of fish using turmeric and salt is common in Malaysia, it gives an excellent flavour and gains the public interest on developed this fish marinade with turmeric and salt as a semi preserved and ready to cook fish for consumers as the short mackerel had a high demand in the market. Beside of flavouring purposes, the effect of turmeric-salt marination in inhibiting the microorganisms is still unknown. Therefore, the objective of this study was to determine the effect of the turmeric-salt marination for short mackerel on total microbial and L. monocytogenes count at various storage temperature.

\section{Materials and methods}

\subsection{Sample preparation}

Short mackerel (Rastrelliger brachysoma) was purchased from a local market in Pasar Seri Serdang, Selangor, Malaysia, and kept in the icebox to maintain the temperature at 4 to $6^{\circ} \mathrm{C}$ and brought to the laboratory at Universiti Putra Malaysia. The time interval from the market to the laboratory was around 20 mins. The samples were washed and cleaned by removing the gut, head, and tail. The samples were weighed and measured to get the exact weight and length. The fillets were measured using a ruler to get the same measurement, 8 $\mathrm{cm} \times 4 \mathrm{~cm}(25 \mathrm{~g})$. The samples were dipped into $70 \%$ ethanol to remove the background microflora for about 1 minute. The treatment with $70 \% \mathrm{EtOH}$ for $60 \mathrm{~s}$ reduced the population of natural microorganisms by approximately $1 \log$ CFU/g (Ukuku and Fett, 2002). After that, the samples were put under laminar flow for 1 hour to dry the ethanol residue (Bourdoux et al., 2018). Then, the samples were placed in a sterile stomacher bag (Bag filter, Interscience, France) and inoculated with $L$. monocytogenes by using micropipettes for $100 \mu \mathrm{L}$. The treatments used in this study was marinating the short mackerel with turmeric and salt. After inoculation, all bags were hand-shaken for $1 \mathrm{~min}$ to disperse the bacterial cells. 


\subsection{Experimental design}

Short mackerel were divided into two groups which consist of control and treatment. For treatment, the sodium chloride crystal was added with the commercial turmeric powder in the sample bag contained with short mackerel. The part of short mackerel used in this experiment were the fillets. In order to assess the effect of marinating on L. monocytogenes, the experiment was arranged in a factorial design (Ekhtiarzadeh et al., 2012). This design included one level of turmeric + salt $(1: 1)$, six storage temperatures $\left(0,5,10,15,20\right.$ and $\left.25^{\circ} \mathrm{C}\right)$ as an isothermal condition, and repeated examinations for growth (microbial count) in marinated and nonmarinated short mackerel at eight intervals $(0,3,6,9,12$, 15, 18, and 21 days). All experiments were conducted in independent triplicate. The samples were taken at appropriate time intervals to allow for an efficient kinetic analysis of microbial growth (Zhang et al., 2011). The fillets experimented every three days for 21 days under the same temperature.

\subsection{Microbiological analysis}

\subsubsection{Bacterial strains and preparation of inoculum}

One strain of L. monocytogenes ATCC 19112 was used in this study. ATCC 19112 strains are part of the products from a company headquartered in St. Cloud, Minnesota, USA. This strain was isolated from the spinal fluid of man in Scotland. Before used, the strains stored on $-80^{\circ} \mathrm{C}$, were revived in $10 \mathrm{~mL}$ of Brain Heart Infusion (BHI, Oxoid, England) for $24 \mathrm{hrs}$ at $37^{\circ} \mathrm{C}$. After $24 \mathrm{hrs,}$ the strains were streaked on Tryptic Soya Agar (TSA, Oxoid, England). One colony was taken from the selective medium, and TSA slants were inoculated and incubated for $24 \mathrm{hrs}$ at $37^{\circ} \mathrm{C}$. These working cultures were stored at $4^{\circ} \mathrm{C}$ for up to 1 month (Li et al., 2016). The bacterial cells were separated from BHI by triple centrifugation at $6000 \mathrm{rpm}$ for 5 mins. During the last two centrifuge runs, the supernatants were removed, and $10 \mathrm{~mL}$ peptone water was added. Dilutions of $L$. monocytogenes cultures $\left(\mathrm{OD}{ }_{600} \mathrm{~nm}=0.1\right)$ were prepared in $0.1 \%(\mathrm{w} / \mathrm{v})$ peptone water (PW, Oxoid, England). The bacterial count was determined by the optical density (OD) method at $600 \mathrm{~nm}$, a population of $1 \times 10^{8}$ cells $/ \mathrm{mL}$ (according to the pre-test, $0.1-0.08$ OD was equal to (1 x $10^{8}$ cells $/ \mathrm{mL}$ ) (Abdollahzadeh et al., 2016).

\subsubsection{Total microbial count}

The samples were retrieved in a sterile stomacher bag (Bag filter, Interscience, France) and diluted with 1:10 in peptone water (PW, Oxoid, England) followed by 2 mins stomaching. After homogenization, serial dilutions (6 dilutions per sample) were performed, and the sample was spread plated ( 2 plates per dilution, 0.1
$\mathrm{mL}$ spread plated) on Plate Count Agar (PCA, Oxoid, England) at $37^{\circ} \mathrm{C}$ for $48-72 \mathrm{hrs}$.

\subsubsection{Listeria monocytogenes count}

The samples were retrieved in a sterile stomacher bag (Bag filter, Interscience, France) and diluted with 1:10 in peptone water (PW, Oxoid, England) followed by 2 min stomaching. After homogenization, serial dilutions (6 dilutions per sample) were performed, and the sample was spread plated ( 2 plates per dilution, $0.1 \mathrm{~mL}$ spread plated) on PALCAM agar (PALCAM, Oxoid, England). The incubation was performed at $37^{\circ} \mathrm{C}$ for $48 \mathrm{hrs}$ for $L$. monocytogenes (Hystead et al., 2013).

\subsection{Physicochemical analysis}

\subsection{1 $\mathrm{pH}$ determination}

For $\mathrm{pH}$ determination, $5 \mathrm{~g}$ of marinated and nonmarinated short mackerel was stomached for 2 mins and transferred into a plastic centrifuge tube. The $\mathrm{pH}$ of the sample was measured with a Corning $\mathrm{pH}$ meter. Determinations of $\mathrm{pH}$ were performed in triplicate at room temperature.

\subsubsection{Water activity determination}

For water activity determination, the water activity $\left(a_{w}\right)$ of marinated and non-marinated short mackerel was measured by using a water activity meter. Determinations of $a_{w}$ were also performed in triplicate at room temperature.

\subsection{Statistical analysis}

The data was collected and calculated with the program EXCEL from Microsoft Office 2017. The obtained data were statistically analyzed using MINITAB. All experiments were performed in triplicate on separation time, and the results are expressed as averages for each experiment. All error bars showed in the figures represent the standard deviation above and below the mean.

\section{Results and discussion}

3.1 Total microbial count of marinated and nonmarinated short mackerel at different storage temperature and time

The growth of microbial count depends on the environment, whether temperature, $\mathrm{pH}$, water activity and others. Temperature is essential in fresh fish because the temperature determines the rate of microbial activity (Giannakourou et al., 2005). Fish can associate with two types of bacteria pathogen which were non-indigenous (Clostridium botulinum, Listeria monocytogenes, Staphylococcus aureus, Salmonella species, Shigella species, Escherichia coli, etc.) and indigenous (Vibrio 
species, Aeromonas species, etc.). Short mackerel contains high water contains and some microorganisms can grow upon storage and through handling the fish (Eze et al., 2011). The enzymatic, and chemical reactions normally contribute to the initial loss of freshness and for the spoilage and products, shelf life is from microbial activity (Pal et al., 2016).

Based on Table 1 it shows the growth of microbial count in non-marinated short mackerel for 21 days in six different temperature in every three days. As in Table 1 shows that at temperature $0^{\circ} \mathrm{C}$ there were no significant differences from 0 days until 18 days but there was a significant difference at 0 day and 21 days which were $\log 4.87 \mathrm{CFU} / \mathrm{g}$ and $\log 6.86 \mathrm{CFU} / \mathrm{g}$ respectively. The maximum growth for the microbial count was at $25^{\circ} \mathrm{C}$ for 18 days which $\log 9.41 \mathrm{CFU} / \mathrm{g}$. Microbial growth occurs due to environmental factors such as $\mathrm{pH}$, temperature and water activity. The concentrations of specific spoilage organisms were lower at 0 days but then increased throughout the storage (Giannakourou et al., 2005). The rate of microbial activity was determined by temperature, and it is known as the primary source of spoilage for the fresh stage of the distribution chain, it produces a quality loss for the product (Giannakourou et al., 2005). Few studies discussed the foodborne pathogens in specific foods that contained $L$. monocytogenes from imported beef, local beef and fermented fish (Hayadi, 2011). Based on the observation of non-marinated short mackerel, there were some visible spots with white mould, unpleasant smell, and the short mackerel turn watery because of the moisture from the short mackerel itself. The quality of the fish is defined as the rate of degradation through microbiological, chemical and physical forms of deterioration (Caldera, 2013).

Table 2 shows the growth of microbial count in marinated short mackerel from 0 days until 21 days. There was no significant difference for temperature $0^{\circ} \mathrm{C}$ and $10^{\circ} \mathrm{C}$ throughout 21 days. The maximum growth of microbial count for $0^{\circ} \mathrm{C}$ was $\log 5.62$ at 18 days. According to a study stated, these methods, including preservation by biological which is biopreservation, and the marinating process does not eliminate microbial growth but only slow down the growth (Fallah et al., 2013). The maximum growth of microbial count in marinated short mackerel was $\log 8.45 \mathrm{CFU} / \mathrm{g}$ at 18 days for $25^{\circ} \mathrm{C}$. The difference between the growth of microbial count in non-marinated and marinated was rather visible because the growth was lower when the short mackerel was marinated with turmeric and salt. In

Table 1. Total microbial count of non-marinated short mackerel at different storage temperature $\left(0,5,10,15,20\right.$ and $\left.25^{\circ} \mathrm{C}\right)$ for 21 days

\begin{tabular}{ccccccc}
\hline Incubation & \multicolumn{5}{c}{ Temperature } \\
\cline { 2 - 7 } Time (day) & 0 & 5 & 10 & 15 & 20 & 25 \\
\hline 0 & $4.87 \pm 0.67^{\mathrm{bA}}$ & $5.18 \pm 0.86^{\mathrm{aA}}$ & $5.09 \pm 0.59^{\mathrm{bA}}$ & $6.17 \pm 0.16^{\mathrm{dA}}$ & $6.08 \pm 0.014^{\mathrm{dA}}$ & $6.27 \pm 0.21^{\mathrm{eA}}$ \\
3 & $4.94 \pm 0.61^{\mathrm{bC}}$ & $6.23 \pm 0.47^{\mathrm{aBC}}$ & $6.26 \pm 0.34^{\mathrm{abBC}}$ & $7.93 \pm 0.60^{\mathrm{cA}}$ & $6.65 \pm 0.67^{\mathrm{cdAB}}$ & $7.25 \pm 0.043^{\mathrm{dAB}}$ \\
6 & $5.03 \pm 0.35^{\mathrm{bB}}$ & $6.56 \pm 0.96^{\mathrm{aAB}}$ & $7.21 \pm 0.89^{\mathrm{aA}}$ & $8.21 \pm 0.73^{\mathrm{bcA}}$ & $7.23 \pm 0.92^{\mathrm{bcdA}}$ & $8.19 \pm 0.26^{\mathrm{cA}}$ \\
9 & $5.44 \pm 0.49^{\mathrm{abC}}$ & $7.12 \pm 1.04^{\mathrm{aBC}}$ & $7.59 \pm 0.62^{\mathrm{aAB}}$ & $9.22 \pm 0.15^{\mathrm{aA}}$ & $7.99 \pm 0.51^{\mathrm{abcAB}}$ & $8.55 \pm 0.50^{\mathrm{bcAB}}$ \\
12 & $5.63 \pm 0.43^{\mathrm{abC}}$ & $7.50 \pm 1.14^{\mathrm{aB}}$ & $7.61 \pm 0.42^{\mathrm{aAB}}$ & $9.22 \pm 0.12^{\mathrm{aA}}$ & $8.60 \pm 0.61^{\mathrm{abAB}}$ & $9.12 \pm 0.43^{\mathrm{abAB}}$ \\
15 & $6.27 \pm 1.17^{\mathrm{abB}}$ & $7.69 \pm 1.18^{\mathrm{aAB}}$ & $7.85 \pm 0.47^{\mathrm{aAB}}$ & $9.26 \pm 0.13^{\mathrm{aA}}$ & $8.97 \pm 0.55^{\mathrm{aA}}$ & $9.37 \pm 0.059^{\mathrm{abA}}$ \\
18 & $6.63 \pm 0.54^{\mathrm{abC}}$ & $7.70 \pm 1.11^{\mathrm{aBC}}$ & $7.45 \pm 0.70^{\mathrm{aC}}$ & $9.27 \pm 0.18^{\mathrm{aAB}}$ & $9.25 \pm 0.27^{\mathrm{aAB}}$ & $9.41 \pm 0.15^{\mathrm{aA}}$ \\
21 & $6.86 \pm 0.51^{\mathrm{aC}}$ & $7.71 \pm 0.64^{\mathrm{aBC}}$ & $7.82 \pm 0.39^{\mathrm{aBC}}$ & $9.06 \pm 0.09^{\mathrm{abA}}$ & $8.78 \pm 0.4^{\mathrm{abAB}}$ & $9.34 \pm 0.37^{\mathrm{abA}}$ \\
\hline
\end{tabular}

Values with the same lower-case superscript letters in each column are not significantly different $(\mathrm{P}>0.05)$. Values with the different upper-case superscript letters in the same row are significantly different $(\mathrm{P}<0.05)$.

Table 2. Total microbial count of marinated (turmeric-salt, $1: 1)$ short mackerel at different storage temperature $(0,5,10,15,20$ and $25^{\circ} \mathrm{C}$ ) for 21 days

\begin{tabular}{ccccccc}
\hline Incubation & \multicolumn{5}{c}{ Temperature } \\
\cline { 2 - 7 } Time (day) & 0 & 5 & 10 & 15 & 20 & 25 \\
\hline 0 & $5.16 \pm 0.31^{\mathrm{aA}}$ & $4.82 \pm 0.62^{\mathrm{bA}}$ & $5.33 \pm 0.78^{\mathrm{aA}}$ & $5.17 \pm 0.36^{\mathrm{bA}}$ & $5.44 \pm 0.050^{\mathrm{cA}}$ & $5.55 \pm 0.25^{\mathrm{cA}}$ \\
3 & $4.58 \pm 0.68^{\mathrm{aA}}$ & $5.43 \pm 0.63^{\mathrm{abA}}$ & $5.38 \pm 0.89^{\mathrm{aA}}$ & $5.61 \pm 0.80^{\mathrm{abA}}$ & $6.18 \pm 0.70^{\mathrm{bcA}}$ & $5.84 \pm 0.40^{\mathrm{cA}}$ \\
6 & $4.90 \pm 0.25^{\mathrm{aA}}$ & $5.19 \pm 0.11^{\mathrm{abA}}$ & $5.84 \pm 1.12^{\mathrm{aA}}$ & $6.11 \pm 1.21^{\mathrm{abA}}$ & $6.92 \pm 0.45^{\mathrm{abA}}$ & $6.58 \pm 0.83^{\mathrm{bcA}}$ \\
9 & $4.91 \pm 0.17^{\mathrm{aD}}$ & $5.25 \pm 0.09^{\mathrm{abCD}}$ & $6.00 \pm 0.81^{\mathrm{aBCD}}$ & $6.49 \pm 0.63^{\mathrm{abABC}}$ & $7.18 \pm 0.17^{\mathrm{abAB}}$ & $7.42 \pm 0.70^{\mathrm{abA}}$ \\
12 & $5.16 \pm 0.26^{\mathrm{aC}}$ & $5.35 \pm 0.06^{\mathrm{abBC}}$ & $5.16 \pm 0.21^{\mathrm{aC}}$ & $6.24 \pm 0.10^{\mathrm{abB}}$ & $7.65 \pm 0.51^{\mathrm{aA}}$ & $8.00 \pm 0.51^{\mathrm{aA}}$ \\
15 & $5.45 \pm 0.37^{\mathrm{aB}}$ & $6.18 \pm 0.95^{\mathrm{aAB}}$ & $6.33 \pm 1.35^{\mathrm{aAB}}$ & $6.68 \pm 0.62^{\mathrm{abAB}}$ & $7.89 \pm 0.46^{\mathrm{aA}}$ & $8.09 \pm 0.25^{\mathrm{aA}}$ \\
18 & $5.62 \pm 0.51^{\mathrm{aD}}$ & $6.12 \pm 0.11^{\mathrm{abCD}}$ & $5.64 \pm 1.05^{\mathrm{aD}}$ & $7.09 \pm 0.14^{\mathrm{aBC}}$ & $8.16 \pm 0.15^{\mathrm{aAB}}$ & $8.45 \pm 0.051^{\mathrm{aA}}$ \\
21 & $5.20 \pm 0.31^{\mathrm{aC}}$ & $6.20 \pm 0.012^{\mathrm{aBC}}$ & $6.12 \pm 0.73^{\mathrm{aBC}}$ & $7.22 \pm 0.15^{\mathrm{aAB}}$ & $7.44 \pm 0.60^{\mathrm{abA}}$ & $8.24 \pm 0.25^{\mathrm{aA}}$ \\
\hline
\end{tabular}

Values with the same lower-case superscript letters in each column are not significantly different $(\mathrm{P}>0.05)$. Values with the different upper-case superscript letters in the same row are significantly different $(\mathrm{P}<0.05)$. 
order to produce a safe, hygienic product that has a reasonable shelf life and acceptable to the consumer, there must be a variety of processing and preservation methods used (Ryser, 1957).

\subsection{Log reduction of total microbial count in marinated short mackerel at different storage temperature and time}

Table 3 shows the $\log$ reduction for the total microbial count in marinated short mackerel for 21 days. The $\log$ reduction from 0 days until 21 days show an increment for $0^{\circ} \mathrm{C}$ and $20^{\circ} \mathrm{C}$ respectively. Marinating with turmeric and salt can reduce the total population of microbial count in short mackerel. The highest reduction for the total microbial count was $2.98 \log \mathrm{CFU} / \mathrm{g}$. For temperatures $5^{\circ} \mathrm{C}, 10^{\circ} \mathrm{C}$ and $15^{\circ} \mathrm{C}$, it presented the increment until day 12 , but after that, the total $\log$ reduction was decreased. It is because there was contamination during the process of marinating and handling the short mackerel. Also, the ingredient used for marinade consists of turmeric which has antioxidant effect and salt that support the marinade (Maktabi et al., 2016). The growth of bacteria in short mackerel was considered as an essential factor to the spoilage. As the initial number of bacteria in the fish was about 3.0 to 4.0 $\log \mathrm{CFU} / \mathrm{g}$. This was proved in a study by Maktabi et al. (2016) that found out that the microbial load decreased after the shrimps were marinated.
3.3 Listeria monocytogenes count of marinated and nonmarinated short mackerel at different temperature and time

One of the studies stated that L. monocytogenes contaminated in water could reach enough numbers to generate human infections (Ryser, 1957). The probability of the L. monocytogenes to contaminate water was probable and L. monocytogenes-contaminated water might play as an indirect source of human infections from marine or freshwater fish or seafood harvested and stored for extended times under refrigeration (Ryser, 1957). Table 4 tabulates the growth of L. monocytogenes in non-marinated short mackerel for different temperature in 21 days. Based on Table 4, there were no significant differences from 0 days to 21 days at the temperature $0^{\circ} \mathrm{C}, 5^{\circ} \mathrm{C}, \quad 10^{\circ} \mathrm{C}$, and $25^{\circ} \mathrm{C}$, but for temperature $15^{\circ} \mathrm{C}$ and $20^{\circ} \mathrm{C}$ with the different day there were significant differences from 0 days to $3,6,9,12$, and 15 days. There is a vast amount of literature on the characteristics of L. monocytogenes as a psychotropic microorganism, and it can grow under minimum growth temperature (Fallah et al., 2013). As observed in Table 4, it shows some increment in the growth of $L$. monocytogenes at $0^{\circ} \mathrm{C}$ from $\log 4.98 \mathrm{CFU} / \mathrm{g}$ to $\log 5.22$ $\mathrm{CFU} / \mathrm{g}$. L. monocytogenes have the ability to grow in the refrigerated temperature range $\left(0.5-3^{\circ} \mathrm{C}\right)$ (Novotny et al., 2004; Fallah et al., 2013). The growth of $L$. monocytogenes in non-marinated short mackerel versus temperature and incubation day had a p-value less than

Table 3. The total of $\log$ reduction for the total microbial count in marinated short mackerel at different storage temperature $(0$, $5,10,15,20$ and $25^{\circ} \mathrm{C}$ ) for 21 days

\begin{tabular}{ccccccccc}
\hline \multirow{2}{*}{ Temperature $\left({ }^{\circ} \mathrm{C}\right)$} & \multicolumn{7}{c}{ Incubation Time (days) } \\
\cline { 2 - 8 } & 0 & 3 & 6 & 9 & 12 & 15 & 18 & 21 \\
\hline 0 & 0.31 & 0.36 & 0.14 & 0.53 & 0.47 & 0.82 & 1.01 & 1.66 \\
5 & 0.36 & 0.8 & 1.37 & 1.85 & 2.15 & 1.5 & 1.58 & 1.51 \\
10 & -0.24 & 0.88 & 1.36 & 1.59 & 2.45 & 1.51 & 1.81 & 1.7 \\
15 & 0.99 & 2.32 & 2.1 & 2.72 & 2.98 & 2.58 & 2.18 & 1.85 \\
20 & 0.64 & 0.47 & 0.31 & 0.81 & 0.95 & 1.08 & 1.1 & 1.34 \\
25 & 0.73 & 1.41 & 1.62 & 1.14 & 1.11 & 1.28 & 0.96 & 1.11 \\
\hline
\end{tabular}

Table 4. Listeria monocytogenes count of non-marinated short mackerel at different storage temperature $\left(0,5,10,15,20\right.$ and $25^{\circ}$ C) for 21 days

\begin{tabular}{ccccccc}
\hline \multirow{2}{*}{$\begin{array}{c}\text { Incubation } \\
\text { Time (day) }\end{array}$} & 0 & 5 & 10 & 15 & 20 & 25 \\
\cline { 2 - 7 } & $4.98 \pm 1.13^{\mathrm{aA}}$ & $5.07 \pm 0.88^{\mathrm{aA}}$ & $4.68 \pm 0.83^{\mathrm{aA}}$ & $6.17 \pm 0.19^{\mathrm{bA}}$ & $6.16 \pm 0.091^{\mathrm{bA}}$ & $6.22 \pm 0.18^{\mathrm{aA}}$ \\
3 & $4.52 \pm 0.54^{\mathrm{aC}}$ & $5.60 \pm 1.06^{\mathrm{aABC}}$ & $5.41 \pm 1.43^{\mathrm{aBC}}$ & $7.78 \pm 0.53^{\mathrm{aA}}$ & $6.63 \pm 0.70^{\mathrm{abABC}}$ & $6.96 \pm 0.47^{\mathrm{aAB}}$ \\
6 & $4.79 \pm 0.79^{\mathrm{aB}}$ & $5.68 \pm 1.07^{\mathrm{aAB}}$ & $6.83 \pm 1.20^{\mathrm{aAB}}$ & $7.74 \pm 0.71^{\mathrm{aA}}$ & $7.42 \pm 0.20^{\mathrm{abA}}$ & $7.231 \pm 0.17^{\mathrm{aA}}$ \\
9 & $4.96 \pm 0.66^{\mathrm{aB}}$ & $5.76 \pm 0.68^{\mathrm{aAB}}$ & $6.29 \pm 1.68^{\mathrm{aAB}}$ & $7.89 \pm 0.53^{\mathrm{aA}}$ & $7.83 \pm 0.43^{\mathrm{abA}}$ & $7.56 \pm 0.36^{\mathrm{aA}}$ \\
12 & $5.30 \pm 0.66^{\mathrm{aB}}$ & $6.41 \pm 1.06^{\mathrm{aAB}}$ & $6.84 \pm 0.84^{\mathrm{aAB}}$ & $7.64 \pm 0.52^{\mathrm{aA}}$ & $7.51 \pm 0.53^{\mathrm{abA}}$ & $7.56 \pm 0.68^{\mathrm{aA}}$ \\
15 & $4.53 \pm 0.33^{\mathrm{aB}}$ & $6.79 \pm 0.50^{\mathrm{aA}}$ & $6.79 \pm 1.04^{\mathrm{aA}}$ & $7.69 \pm 0.15^{\mathrm{aA}}$ & $7.61 \pm 0.49^{\mathrm{abA}}$ & $7.79 \pm 0.43^{\mathrm{aA}}$ \\
18 & $5.30 \pm 0.068^{\mathrm{aB}}$ & $6.93 \pm 0.53^{\mathrm{aAB}}$ & $6.56 \pm 1.10^{\mathrm{aAB}}$ & $7.54 \pm 0.60^{\mathrm{abA}}$ & $8.16 \pm 0.34^{\mathrm{aA}}$ & $7.48 \pm 0.82^{\mathrm{aA}}$ \\
21 & $5.22 \pm 0.24^{\mathrm{aA}}$ & $6.88 \pm 0.63^{\mathrm{aA}}$ & $6.91 \pm 0.48^{\mathrm{aA}}$ & $7.02 \pm 0.58^{\mathrm{abA}}$ & $7.23 \pm 1.28^{\mathrm{abA}}$ & $7.16 \pm 0.99^{\mathrm{aA}}$ \\
\hline
\end{tabular}

Values with the same lower-case superscript letters in each column are not significantly different $(\mathrm{P}>0.05)$. Values with the different upper-case superscript letters in the same row are significantly different $(\mathrm{P}<0.05)$. 
0.05, which mean there was a significant difference.

Based on Table 4 the maximum growth of $L$. monocytogenes in non-marinated short mackerel was log $8.16 \mathrm{CFU} / \mathrm{g}$ at $20^{\circ} \mathrm{C}$ for 18 days and the minimum growth of L. monocytogenes in non-marinated short mackerel was $\log 4.52 \mathrm{CFU} / \mathrm{g}$ at $0^{\circ} \mathrm{C}$ for three days. At temperature $0^{\circ} \mathrm{C}$, the growth of $L$. monocytogenes was increased but slower because the growth was suppressed. The capability of L. monocytogenes that can grow at low temperatures raises the risk of food infection (Tang et al., 2013). The trend for the growth of L. monocytogenes was unbalanced because $L$. monocytogenes need to adapt to the temperature.

The growth of L. monocytogenes in the Table 5 shows there was no significant differences for temperature $0^{\circ} \mathrm{C}, 5^{\circ} \mathrm{C}, 10^{\circ} \mathrm{C}$ and $15^{\circ} \mathrm{C}$ and as for $20^{\circ} \mathrm{C}$ and $25^{\circ} \mathrm{C}$ there were significant differences for different days. At temperature $20^{\circ} \mathrm{C}$ only $0,9,12$, and 18 days had significant differences. The p-value for the growth of $L$. monocytogenes versus incubation time and the temperature was 0.011 , which was below than 0.05 . The maximum growth for $L$. monocytogenes in marinated short mackerel was Log $7.19 \mathrm{CFU} / \mathrm{g}$ at $20^{\circ} \mathrm{C}$ for nine days. There was a difference in the growth of $L$. monocytogenes in marinated and non-marinated short mackerel which seen that the growth of $L$. monocytogenes in marinated lower than in nonmarinated short mackerel. The growth was affected by the turmeric, which contains curcumin that reacts as antioxidant, antibacterial, antifungal and antiviral activities (Abdollahzadeh et al., 2014). Based on Ryser (1957), L. monocytogenes is different from another foodborne pathogen because it can tolerate (up till 20\%) salt concentrations and can multiply over a wide range of temperatures $\left(1\right.$ to $45^{\circ} \mathrm{C}$ ), also can adapt to the stress situation.

\subsection{Log reduction of Listeria monocytogenes in marinated short mackerel at different temperature and} time

The initial reduction in L. monocytogenes count observed according to the marinades with turmeric and salt. According to a study from Maktabi et al. (2016), the log reduction of $L$. monocytogenes in marinated short mackerel was calculated by subtracting the growth of marinated short mackerel with non-marinated short mackerel. Table 6 presents the highest log reduction for L. monocytogenes was $2.81 \log \mathrm{CFU} / \mathrm{g}$ at $5^{\circ} \mathrm{C}$ for 21 days. Hence, marinated with turmeric and salt can reduce the growth of L. monocytogenes count in short mackerel from $0.07 \log \mathrm{CFU} / \mathrm{g}$ until $2.81 \log \mathrm{CFU} / \mathrm{g}$. During the whole incubation time, at $0^{\circ} \mathrm{C}$, the $\log$ reduction was not so high. L. monocytogenes turn out to survive longer under environmental conditions focusing on the ability of L. monocytogenes to colonize, multiply and remain in the food processing environment and food processing equipment (Ryser, 1957). Salt and pH work as a control

Table 5. Listeria monocytogenes count of a marinated (turmeric-salt, 1:1) short mackerel at different storage temperature $(0,5$, $10,15,20$ and $25^{\circ} \mathrm{C}$ ) for 21 days

\begin{tabular}{ccccccc}
\hline Incubation & \multicolumn{7}{c}{ Temperature } \\
\cline { 2 - 7 } Time (day) & 0 & 5 & 10 & 15 & 20 & 25 \\
\hline 0 & $4.37 \pm 0.79^{\mathrm{aA}}$ & $4.04 \pm 0.11^{\mathrm{aA}}$ & $4.71 \pm 1.22^{\mathrm{aA}}$ & $5.38 \pm 0.10^{\mathrm{aA}}$ & $5.28 \pm 0.065^{\mathrm{bA}}$ & $5.21 \pm 0.24^{\mathrm{cA}}$ \\
3 & $4.44 \pm 0.46^{\mathrm{aA}}$ & $4.76 \pm 0.88^{\mathrm{aA}}$ & $4.45 \pm 1.12^{\mathrm{aA}}$ & $5.60 \pm 0.69^{\mathrm{aA}}$ & $5.74 \pm 0.68^{\mathrm{abA}}$ & $5.53 \pm 0.46^{\mathrm{bcA}}$ \\
6 & $4.04 \pm 0.22^{\mathrm{aB}}$ & $4.26 \pm 0.04^{\mathrm{aB}}$ & $5.22 \pm 1.55^{\mathrm{aAB}}$ & $5.93 \pm 1.02^{\mathrm{aAB}}$ & $6.41 \pm 0.12^{\mathrm{abA}}$ & $5.29 \pm 0.023^{\mathrm{cAB}}$ \\
9 & $4.13 \pm 0.14^{\mathrm{aC}}$ & $4.53 \pm 0.34^{\mathrm{aBC}}$ & $4.93 \pm 1.34^{\mathrm{aBC}}$ & $6.25 \pm 0.77^{\mathrm{aAB}}$ & $7.19 \pm 0.099^{\mathrm{aA}}$ & $7.12 \pm 0.10^{\mathrm{aA}}$ \\
12 & $4.25 \pm 0.13^{\mathrm{aC}}$ & $4.61 \pm 0.42^{\mathrm{aBC}}$ & $4.89 \pm 0.57^{\mathrm{aBC}}$ & $6.02 \pm 0.96^{\mathrm{aAB}}$ & $7.10 \pm 0.14^{\mathrm{aA}}$ & $6.78 \pm 0.49^{\mathrm{aA}}$ \\
15 & $4.19 \pm 0.36^{\mathrm{aB}}$ & $4.75 \pm 1.14^{\mathrm{aAB}}$ & $5.11 \pm 1.65^{\mathrm{aAB}}$ & $5.22 \pm 0.21^{\mathrm{aAB}}$ & $6.94 \pm 0.51^{\mathrm{abA}}$ & $6.53 \pm 0.21^{\mathrm{abAB}}$ \\
18 & $4.32 \pm 0.59^{\mathrm{aB}}$ & $4.27 \pm 0.69^{\mathrm{aB}}$ & $4.67 \pm 0.90^{\mathrm{aB}}$ & $5.68 \pm 0.57^{\mathrm{aAB}}$ & $7.07 \pm 0.65^{\mathrm{aA}}$ & $6.15 \pm 0.74^{\mathrm{abcAB}}$ \\
21 & $4.15 \pm 0.11^{\mathrm{aB}}$ & $4.06 \pm 0.59^{\mathrm{aB}}$ & $4.50 \pm 0.68^{\mathrm{aAB}}$ & $5.67 \pm 0.091^{\mathrm{aAB}}$ & $6.29 \pm 1.28^{\mathrm{abA}}$ & $6.17 \pm 0.41^{\mathrm{abcA}}$ \\
\hline
\end{tabular}

Values with the same lower-case superscript letters in each column are not significantly different $(\mathrm{P}>0.05)$. Values with the different upper-case superscript letters in the same row are significantly different $(\mathrm{P}<0.05)$.

Table 6. The total of log reduction for Listeria monocytogenes count in marinated short mackerel at different storage temperature $\left(0,5,10,15,20\right.$ and $\left.25^{\circ} \mathrm{C}\right)$ for 21 days

\begin{tabular}{ccccccccc}
\hline \multirow{2}{*}{ Temperature $\left({ }^{\circ} \mathrm{C}\right)$} & \multicolumn{7}{c}{ Incubation Time (days) } \\
\cline { 2 - 8 } & 0 & 3 & 6 & 9 & 12 & 15 & 18 & 21 \\
\hline 0 & 0.61 & 0.07 & 0.75 & 0.83 & 1.05 & 0.34 & 0.97 & 1.07 \\
5 & 1.02 & 0.85 & 1.41 & 1.23 & 1.80 & 2.04 & 2.66 & 2.81 \\
10 & -0.03 & 0.96 & 1.61 & 1.35 & 1.95 & 1.68 & 1.89 & 2.41 \\
15 & 0.79 & 2.19 & 1.80 & 1.63 & 1.62 & 2.47 & 1.85 & 1.35 \\
20 & 0.88 & 0.89 & 1.01 & 0.64 & 0.41 & 0.66 & 1.09 & 0.94 \\
25 & 1.01 & 1.43 & 1.94 & 0.44 & 0.78 & 1.26 & 1.33 & 0.99 \\
\hline
\end{tabular}


towards the growth and survival of L. monocytogenes.

\section{$3.5 \mathrm{pH}$ and water activity of marinated and non- marinated short mackerel}

The initial $\mathrm{pH}$ in fresh fish usually in neutral range but along the experiment, the $\mathrm{pH}$ increased because of the decomposition of the nitrogenous compound during storage (Table 7). This can be observed in Maktabi (2016) when the $\mathrm{pH}$ was increased the product loss quality. According to Caldera (2013), the concentration of SSOs are low at the beginning, but during the storage, their growth was faster compared to other microorganisms and produced metabolites and enzymes to cause spoilage. The quality of the fish is must be maintained from catching the fish until the storage of the fish. The spoilage that happened from the fresh fish usually from the monitoring and controlling of storage temperature. According to Delgado-Pando et al. (2018), salt contributes to salty taste, flavour, and texture directly as the water-binding properties also as preservatives to the short mackerel. It can give an effect on microbial and enzymatic activity. As cells contain $80 \%$ to $90 \%$ of water, the osmotic pressure was happening because high osmotic pressure removes water from cells, and it causes the shrinkage of the cell membrane. As stated in the Table 7, there were a few differences in $\mathrm{pH}$ value between non-marinated and marinated short mackerel. It is known that high salt-reduced microbial growth by reducing water activity (Burall et al., 2015). Throughout the incubation time, there was increment on the $\mathrm{pH}$ value for non-marinated and marinated short mackerel. The $\mathrm{pH}$ and water activity of non-marinated short mackerel was 6.25 and 0.9878 respectively and were in the range that supports the growth of microorganism (Li et al., 2016).

\section{Conclusion}

In conclusion, the study shows that the marination using turmeric-salt for short mackerel results in slower the growth of Listeria monocytogenes compared to the non-marinated short mackerel. Storage at a lower temperature, 0 and $5^{\circ} \mathrm{C}$ were also determined could assist in reducing the L. monocytogenes growth.

\section{Conflict of Interest}

The authors declare no conflict of interest.

\section{Acknowledgments}

The authors would like to thank Ministry of Education Malaysia for financial aid under Fundamental Research Grant Scheme (FRGS/1/2016/STG03/ UPM/02/9).

\section{References}

Abdollahzadeh, E., Ojagh, S.M., Hosseini, H., Irajian, G. and Ghaemi, E.A. (2016). Prevalence and Molecular Characterization of Listeria spp. and Listeria monocytogenes Isolated from Fish, Shrimp, and Cooked Ready-To-Eat (RTE) Aquatic Products In Iran. LWT - Food Science and Technology, 73, 205211. https://doi.org/10.1016/j.lwt.2016.06.020

Abdollahzadeh, E., Rezaei, M. and Hosseini, H. (2014). Antibacterial Activity of Plant Essential Oils and Extracts: The Role Of Thyme Essential Oil, Nisin, and their Combination to Control Listeria monocytogenes Inoculated in Minced Fish Meat. Food Control, 35(1), 177-183. https:// doi.org/10.1016/j.foodcont.2013.07.004

Basheer, V.S., Mohitha, C., Vineesh, N., Divya, P.R., Gopalakrishnan, A. and Jena, J.K. (2015). Molecular Phylogenetics Of Three Species Of The Genus

Table 7. $\mathrm{pH}$ value of marinated and non-marinated short mackerel different storage temperature $\left(0,5,10,15,20\right.$ and $\left.25^{\circ} \mathrm{C}\right)$ for 21 days

\begin{tabular}{clcccccccc}
\hline \multirow{2}{*}{ Temperature $\left({ }^{\circ} \mathrm{C}\right)$} & \multicolumn{7}{c}{ Treatment } & \multicolumn{7}{c}{ Incubation Time (Days) } \\
\cline { 3 - 9 } & & 0 & 3 & 6 & 9 & 12 & 15 & 18 & 21 \\
\hline \multirow{2}{*}{0} & Non marinated & 5.8 & 5.8 & 5.9 & 6.1 & 6.1 & 6.1 & 6.3 & 6.2 \\
& Marinated & 5.8 & 5.8 & 5.8 & 5.8 & 5.9 & 6.0 & 6.0 & 6.0 \\
\hline \multirow{2}{*}{5} & Non marinated & 6.0 & 6.1 & 6.1 & 6.2 & 6.2 & 6.6 & 7.3 & 7.9 \\
& Marinated & 5.9 & 6.0 & 6.0 & 5.9 & 6.0 & 6.0 & 6.0 & 6.1 \\
\hline \multirow{2}{*}{10} & Non marinated & 6.2 & 6.2 & 6.4 & 6.9 & 7.3 & 8.1 & 8.1 & 8.5 \\
& Marinated & 6.1 & 6.1 & 6.3 & 6.2 & 6.0 & 6.1 & 6.1 & 6.3 \\
\hline \multirow{2}{*}{15} & Non marinated & 6.1 & 6.1 & 6.2 & 6.6 & 7.1 & 7.2 & 7.2 & 8.0 \\
& Marinated & 6.1 & 6.1 & 6.1 & 6.1 & 6.1 & 6.2 & 6.4 & 6.3 \\
\hline \multirow{2}{*}{20} & Non marinated & 6.1 & 6.2 & 6.3 & 6.4 & 6.6 & 6.9 & 7.1 & 7.7 \\
& Marinated & 6.0 & 6.0 & 6.1 & 6.1 & 6.1 & 6.2 & 6.2 & 6.0 \\
\hline \multirow{2}{*}{25} & Non marinated & 5.9 & 6.0 & 6.2 & 6.3 & 6.6 & 7.2 & 7.5 & 7.7 \\
& Marinated & 5.9 & 5.9 & 6.1 & 6.1 & 6.1 & 6.2 & 6.1 & 6.1 \\
\hline
\end{tabular}


Rastrelliger Using Mitochondrial DNA Markers. Molecular Biology Reports, 42, 873-879. https:// doi.org/10.1007/s11033-014-3710-8

Bourdoux, S., Rajkovic, A., De Sutter, S., Vermeulen, A., Spilimbergo, S., Zambon, A., Hofland, G., Uyttendaele, M. and Devlieghere, F. (2018). Inactivation of Salmonella, Listeria monocytogenes, and Escherichia coli O157: $\mathrm{H} 7$ inoculated on Coriander by Freeze-drying and Supercritical $\mathrm{CO}_{2}$ Drying. Innovative Food Science and Emerging Technologies, 47, 180-186. https://doi.org/10.1016/ j.ifset.2018.02.007

Buchanan, R.L., Gorris, L.G.M., Hayman, M.M., Jackson, T.C. and Whiting, R.C. (2017). A review of Listeria monocytogenes: An Update On Outbreaks, Virulence, Dose-Response, Ecology, and Risk Assessments. Food Control, 75, 1-13. https:// doi.org/10.1016/j.foodcont.2016.12.016

Burall, L.S., Simpson, A.C., Chou, L., Laksanalamai, P. and Datta, A.R. (2015). A Novel Gene, Lstc, of Listeria monocytogenes is Implicated in High Salt Tolerance. Food Microbiology, 48, 72-82. https:// doi.org/10.1016/j.fm.2014.12.008

Caldera, L. (2013). Identification and Characterization of Specific Spoilage Organisms (SSOs) in Different Food Matrices. Milano, Italy: Universita Degli Studi di Milano, PhD. Thesis.

Chen, J.-Q., Healey, S., Regan, P., Laksanalamai, P. and Hu, Z. (2017). PCR-Based Methodologies For Detection And Characterization of Listeria monocytogenes and Listeria ivanovii in Foods And Environmental Sources. Food Science and Human Wellness, 6(2), 39-59. https://doi.org/10.1016/ j.fshw.2017.03.001

Delgado-Pando, G., Fischer, E., Allen, P., Kerry, J.P., O'Sullivan, M.G. and Hamill, R. M. (2018). Salt Content And Minimum AccepTable Levels In Whole-Muscle Cured Meat Products. Meat Science, 139, 179-186. https://doi.org/10.1016/ j.meatsci.2018.01.025

Ekhtiarzadeh, H., Akhondzadeh Basti, A., Misaghi, A., Sari, A., Khanjari, A., Rokni, N., Abbaszadeh, S. and Partovi, R. (2012). Growth Response of Vibrio parahaemolyticus and Listeria monocytogenes in Salted Fish Fillets as Affected by Zataria multiflora boiss. Essential Oil, Nisin, And Their Combination. Journal of Food Safety, 32(3), 263-269. https:// doi.org/10.1111/j.1745-4565.2012.00376.x

Eze, E.I., Echezona, B. and Uzondinma, E.C. (2011). Isolation and Identification of Pathogenic Bacteria Associated with Frozen Mackerel Fish (Scomber scombrus) in a Humid Tropical Environment. African Journal of Agricultural Research, 6(8), 1947
$-1951$.

Fallah, A.A., Saei-dehkordi, S.S. and Mahzounieh, M. (2013). Occurrence and Antibiotic Resistance Profiles of Listeria monocytogenes Isolated from Seafood Products and Market and Processing Environments in Iran. Food Control, 34(2), 630636. https://doi.org/10.1016/j.foodcont.2013.06.015

Giannakourou, M.C., Koutsoumanis, K., Nychas, G.J.E. and Taoukis, P.S. (2005). Field Evaluation of the Application of Time-Temperature Integrators for Monitoring Fish Quality in the Chill Chain. International Journal of Food Microbiology, 102(3), 323-336.

j.ijfoodmicro.2004.11.037

Gram, L. and Dalgaard, P. (2002). Fish Spoilage Bacteria - Problems and Solutions. Current Opinion in Biotechnology, 13(3), 262-266. https:// doi.org/10.1016/S0958-1669(02)00309-9

Gurresch, A., Gerner, W., Pin, C., Wagner, M. and Hein, I. (2016). Evidence of Metabolically Active but NonCulturable Listeria monocytogenes in Long-Term Growth at $10^{\circ} \mathrm{C}$. Research in Microbiology, 167(4), 334-343.

https://doi.org/10.1016/ j.resmic.2016.01.003

Han, F., Huang, X. and Mahunu, G.K. (2017). Exploratory Review on Safety of Edible Raw Fish Per the Hazard Factors and their Detection Methods. Trends in Food Science and Technology, 59, 37-48. https://doi.org/10.1016/j.tifs.2016.11.004

Hystead, E., Diez-Gonzalez, F. and Schoenfuss, T.C. (2013). The Effect of Sodium Reduction with and without Potassium Chloride on the Survival of Listeria monocytogenes in Cheddar Cheese. Journal of Dairy Science, 96(10), 6172-6185. https:// doi.org/10.3168/jds.2013-6675

Jamali, H., Paydar, M., Ismail, S., Looi, C.Y. and Wong, W.F. (2015). Prevalence, Antimicrobial Susceptibility and Viral Typing of Listeria Species and Listeria monocytogenes Isolated from Open-Air Fish Markets. BMC Microbiology, 15, 1-7. https:// doi.org/10.1186/s12866-015-0476-7

Li, C., Huang, L., Hwang, C.A. and Chen, J. (2016). Growth of Listeria monocytogenes in Salmon Roe A Kinetic Analysis. Food Control, 59(2073), 538545. https://doi.org/10.1016/j.foodcont.2015.06.016

Maktabi, S., Zarei, M. and Chadorbaf, M. (2015). Effect of Traditional Marinating on Bacterial and Chemical Characteristics in Frozen Rainbow Trout Fillet. Journal of Food Quality and Hazards Control, 2(4), 128-133.

Maktabi, S., Zarei, M. and Chadorbaf, M. (2016). Effect of a Traditional Marinating on Properties of 
Rainbow Trout Fillet During Chilled Storage. Veterinary Research Forum: An International Quarterly Journal, 7(4), 295-300.

Nieminen, T.T., Välitalo, H., Säde, E., Paloranta, A., Koskinen, K. and Björkroth, J. (2012). The Effect Of Marination On Lactic Acid Bacteria Communities In Raw Broiler Fillet Strips. Frontiers in Microbiology, 3(OCT), 1-8. https://doi.org/10.3389/ fmicb.2012.00376

Novotny, L., Dvorska, L., Lorencova, A., Beran V. and Pavlik, I. (2004). Fish: A Potential Source of Bacterial Pathogens For Human Beings. Veterinari Medicina, 49, 343-358. https:// doi.org/10.17221/5715-VETMED

Pal, M., Ketema, A., Anberber, M., Mulu, S. and Dutta, Y. (2016). Microbial Quality of Fish and Fish Products Microbial quality of Fish and Fish Products. Beverage and Food World, 43, 46-49.

Ryser, E.T. (1957), Listeria, Listeriosis and Food Safety. $3^{\text {rd }}$ ed. Boca Raton, USA: CRC Press. https:// doi.org/10.1201/9781420015188

Tan, C.W., Malcolm, T.T.H., Kuan, C.H., Thung, T.Y., Chang, W.S., Loo, Y.Y., Premarathne, J.M.K.J.K., Ramzi, O.S.B., Mohd Fadzil, S.N., Nordin, Y., Rukayadi, Y., Nakaguchi, Y., Nishibuchi, M. and Son, R. (2017). Prevalence and Antimicrobial Susceptibility of Vibrio parahaemolyticus Isolated from Short Mackerels (Rastrelliger brachysoma) in Malaysia. Frontiers in Microbiology, 2017, 1087. https://doi.org/10.3389/fmicb.2017.01087

Tang, S., Stasiewicz, M.J., Wiedmann, M., Boor, K.J. and Bergholz, T.M. (2013). Efficacy of Different Antimicrobials on Inhibition of Listeria monocytogenes Growth in Laboratory Medium and on Cold-Smoked Salmon. International Journal of Food Microbiology, 165(3), 265-275. https:// doi.org/10.1016/j.ijfoodmicro.2013.05.018

Ukuku, D.O. and Fett, W. (2002). The behavior of Listeria monocytogenes Inoculated on Cantaloupe Surfaces and Efficacy of Washing Treatments to Reduce Transfer from Rind to Fresh-Cut Pieces. Journal of Food Protection, 65(6), 924-930. https:// doi.org/10.4315/0362-028X-65.6.924

Vlahova-Vangelova, D. and Dragoev, S. (2014). Marination: Effect on Meat Safety and Human Health. A Review. Bulgarian Journal of Agricultural Science, 20(3), 503-509.

Wieczorek, K. and Osek, J. (2017). Prevalence, Genetic Diversity and Antimicrobial Resistance of Listeria monocytogenes Isolated from Fresh and Smoked Fish in Poland. Food Microbiology, 64, 164-171. https://doi.org/10.1016/j.fm.2016.12.022
Zhang, L., Li, X., Lu, W., Shen, H. and Luo, Y. (2011). Quality Predictive Models of Grass Carp ( Ctenopharyngodon idellus) at Different Temperatures During Storage. Food Control, 22(8), 1197-1202. https://doi.org/10.1016/ j.foodcont.2011.01.017 